\title{
Molecular characterization and growth optimization of halo-tolerant amylase producing bacteria isolated from salt mines of Karak, Pakistan
}

\author{
Waqas Shah ${ }^{1}$, Nawab Ali ${ }^{1 *}$, Shahbaz Ahmad ${ }^{1}$, Muhammad Qasim ${ }^{2}$, \\ Hazir Rahman ${ }^{3}$, Sami Ullah ${ }^{1}$, Farman Ullah ${ }^{1}$, Baharullah Khattak ${ }^{2}$ and \\ Muhammad Daud Khan ${ }^{1}$ \\ 1. Department of Biotechnology and Genetic Engineering, Kohat University of Science \& Technology, Kohat- \\ Pakistan \\ 2. Department of Microbiology, Kohat University of Science \& Technology, Kohat-Pakistan \\ 3. Department of Microbiology, Abdul Wali Khan University Mardan, Mardan-Pakistan \\ *Corresponding author's email: nawabali_1857@yahoo.com \\ Citation \\ Waqas Shah, Nawab Ali1, Shahbaz Ahmad, Muhammad Qasim, Hazir Rahman, Sami Ullah, Farman Ullah, \\ Baharullah Khattak and Muhammad Daud Khan. Molecular characterization and growth optimization of halo- \\ tolerant amylase producing bacteria isolated from salt mines of Karak, Pakistan. Pure and Applied Biology. Vol. 6, \\ Issue 1, pp385-393. http://dx.doi.org/10.19045/bspab.2017.60038
}

Received: $16 / 11 / 2016$

Revised: $25 / 02 / 2017$

Accepted: 04/03/2017

Online First: 06/03/2016

\section{Abstract}

Microorganisms are commonly used for the production of different types of enzymes, among which amylases are extensively used for different industrial purposes like food industry, paper industry, textile industry and detergents etc. In this study, extremophilic bacteria were isolated from salt mines of Karak, Pakistan which have the ability to grow and express amylases at diverse environmental conditions. In Total, 43 out of the 53 bacteria were found positive for amylase production. Furthermore, microscopic, biochemical and phylogenetic analysis inferred from 16S rRNA gene sequencing identified that amylase producing strain SBA-5 belong to Bacillus subtilis. The strain SBA-5 identified as Bacillus subtilis exhibited high amylase production at $\mathrm{pH} 9$ and temperature $37^{\circ} \mathrm{C}$. The present study revealed that the salt mines of Karak have high population of halotolerant microorganism feasible for use under diverse environmental conditions, which can be of great importance for various bio-industrial applications.

Keywords: Amylase producing bacteria; Protein purification; Salt mines of Karak

Introduction

Enzymes are biological catalyst used for different reactions within laboratory or in living organisms. Enzymes are usually expressed in plants, animals and microbes. However, the microbes are preferred due to ease of purification, less generation time and economic importance. Among the enzymes amylases are the most important enzymes now a days to hydrolyze starch into dextrin and small polymers of glucose. The cost of amylases is $24 \%$ of the total expenditures in 
the starch industry and amylase production for various applications is the need of the day [1-3]. The enzymes collected from extreme environments will have the ability to perform the reactions at elevated laboratory conditions. Different environmental extremes tolerated by these microbes are much broader than other life forms. The Extremophilic microorganisms can be divided into five groups; thermophilics, acidophilics, alkophilics, halophilics and psychrophilics. This obviously shows the temperament of the environment where these microorganisms are present [4]. Many extremophiles have such characteristics due to which they are considered as useful for marketable applications [5]. There are several commercially important enzymes such as lipases, proteases and amylases which have been isolated from halophiles with the ability to be active and stable at extreme environmental applications. These enzymes have the degrading ability for various substrates such as proteins, carbohydrates and cellulose which can be of importance to various industries. One of the important enzyme is amylases which can be used for hydrolysis of starch. Scientist are still exploring novel amylases which can be active at extreme laboratory conditions and novel amylase amylases active at extreme conditions are important at industrial level applications $[3,6,7]$.

Different areas have different environments due to seasonal variations and due to these seasonal variations, every area has a specific type of microbial life. Pakistan is particularly gifted with a number of extremophilic environments. Several hot springs, glacial areas and salt mines are present in distant areas of Pakistan. These areas are still to be explored for their microbial life as little work has been done in these areas to study their microbial diversity. There are different reports from Pakistan about the importance of extremophiles. The author has also reported the protease producing bacteria and its commercial importance [8]. . However, amylase producing halotolerant bacteria has been seldom reported in this region and that is why the author has widely explored different amylase producing bacteria for their commercial applications in future.

\section{Materials and methods}

\section{Sample collection and bacterial isolation}

Samples collection was done in three different areas of District Karak, Khyber Pakhtunkhwa Pakistan. These three areas were; Saber Abad (SBA), Bahader Khail (BKHA) and Jatta Ismail Khel (JIK). The samples were collected in sterile plastic bags and transferred immediately to the laboratory and stored at $4{ }^{\circ} \mathrm{C}$. Luria Britain (LB) agar medium was used for culturing. $1 \mathrm{gm}$ of soil $/ 1 \mathrm{ml}$ of water was taken and 6 fold dilutions were made for each sample. From 6 fold dilutions, 200 $\mu$ l of each sample was spread on plates containing LB agar medium with a spreader and this was followed by incubation at $37^{\circ} \mathrm{C}$. The incubation time was 72 hours.

\section{Screening of the isolates}

For the selection of amylase producing isolates, starch was added to the medium. The medium was adjusted with $\mathrm{pH}$ ranging from $\mathrm{pH} 7$ up to $\mathrm{pH} 10$. In order to get purified colonies, streak plate method was used. For this purpose, an isolated colony was picked through a sterilized wire loop and inoculated on plates with agar medium containing starch. The cultures were kept at $30^{\circ} \mathrm{C}$ for a period of 72 hours. The clear zones were indicating the starch degradation as a result of amylase enzyme which was released by the bacterial isolates in the medium. The zones were confirmed by flooding the plates with iodine solution. Glycerol stocks of all the isolates were made for future use [8,9]. 


\section{Molecular identification of amylolytic bacterial isolates}

The genomic DNA of the bacterial isolates was extracted according to the method described by Roohi et al. 2012. The agarose gel electrophoresis was performed according the standard protocol [10]. The 16S rRNA gene amplification of the bacterial isolates was carried out through PCR by using the universal 16s primers 9F (5'GAGTTTGATCCTGGCTCAG-3') and 1510R (5' GGCTACCTTGTTACGA-3') The PCR was done through optimized PCR program; initial denaturation 2 minutes, $94^{\circ} \mathrm{C}$, annealing temperature 1 minute, $52^{\circ} \mathrm{C}$, while extension for 2 minutes at $72^{\circ} \mathrm{C}$. For the final extension the time was 10 minutes and temperature was $72^{\circ} \mathrm{C}$. The overall reaction was repeated for 35 cycles. The PCR amplified product was sent to MACROGEN, Korea for sequencing purposes. The sequence was BLAST searched to get the exact nomenclature of the isolate. Phylogenetic tree was obtained using MEGA 6.0 neighbor joining method with a bootstrap value of 1000 [11].

\section{Sodium dodecyl polyacrlamide gel electrophoresis (SDS-PAGE)}

For the estimation of protein contents of the bacterial cells, the isolates were cultured in broth medium containing starch. After incubation, the next step was centrifugation. The centrifugation was carried out at 15000 rpm for 15 minutes and the rough extract was then mixed with an equal volume of tri chloro acetic acid (TCA, 20\% w/v). Total proteins contents were collected by recentrifugation. The total proteins were analyzed through denaturation polyacrylamide gel electrophoresis (SDSPAGE, 12\% w/v). When gel was electrophoresed, then it was lightly shanked in $50 \mathrm{mM}$ Na-phosphate solution of adjusted with $\mathrm{pH} 7$ and $20 \% \quad(\mathrm{v} / \mathrm{v})$ isopropanol solution at room temperature for an hour to remove denatured materials. After removal of denatured materials, it was moved on to renaturation solution $(50 \mathrm{mM} \mathrm{Na}$-phosphate, $5 \mathrm{mM} \beta$-mercaptoethanol, $1 \mathrm{mM}$ Ethylene diamyeltetra acetic acid) and the incubation time was overnight at $4^{\circ} \mathrm{C}$. After renaturation of the unpurified protein contents, the gel was soaked in $50 \mathrm{mM} \mathrm{Na}$ phosphate buffer at $4^{\circ} \mathrm{C}$ for an hour. The gel was then protected with parafilm and incubated at $37^{\circ} \mathrm{C}$ for 4 hours. After staining of the gel with $0.2 \%$ (w/v) Congo-Red and 5 $\mathrm{mM} \mathrm{NaOH}$ for an hour, it was washed with $1 \mathrm{M} \mathrm{NaCl}$ and $5 \mathrm{mM} \mathrm{NaOH}$ overnight to get rid of excess stain from the active bands. For amylase activity, proteins on a gel were stained with Coomassie Brilliant Blue [8,9].

\section{Optimization of amylase production}

Partially purified amylase enzyme produced by the selected isolates was optimized at different $\mathrm{pH}$ and temperature. Optimization of $\mathrm{pH}$ for the activity of amylases was done using buffered substrate at different $\mathrm{pH}$ values $(3,5,7,8,9,10$, and 11). In similar fashion, the enzymes substrate reaction was incubated at different temperatures $(28,30$, $32,35,37,40$, and 45).

\section{Statistical analysis}

All the experiments were repeated in triplicate and their means and standard deviations were calculated by Microsoft Excel Program (2007).

\section{Results and discussion}

Isolation and screening of amylase producing isolates

Pour plate technique was used for the isolation of amylolytic bacteria and a total of 53 bacterial isolates were found. For the purification of isolates, streak plate method was used. Samples were collected from different areas such as, 20 from Jatta Ismail Khel (JIK), 20 from Bahadur Khail (BKHA) and 13 isolates from Sabir Abad (SBA).

For the selection of amylase producing bacteria, the isolates were grown on agar media containing starch. Out of 53 isolates, 
43 isolates were identified as positive for amylase production by producing clear zones around their colonies ranging from small to large clear zones. The amylase activities based on clear zones around the colonies are also reported in previous literature [8, 11-12]. . On the basis of high amylase activity, one isolate was chosen from each area and these three samples were then further characterized. The isolate SBA5 was considered high amylolytic in all samples, which was isolated from the sample collected from Sabir Abad. Similairly, JIK-1.10 and BKH-A were considered high amylolytic isolates isolated from the sample of Jatta Ismail Khel and Bahadur Khel salt mines, respectively.

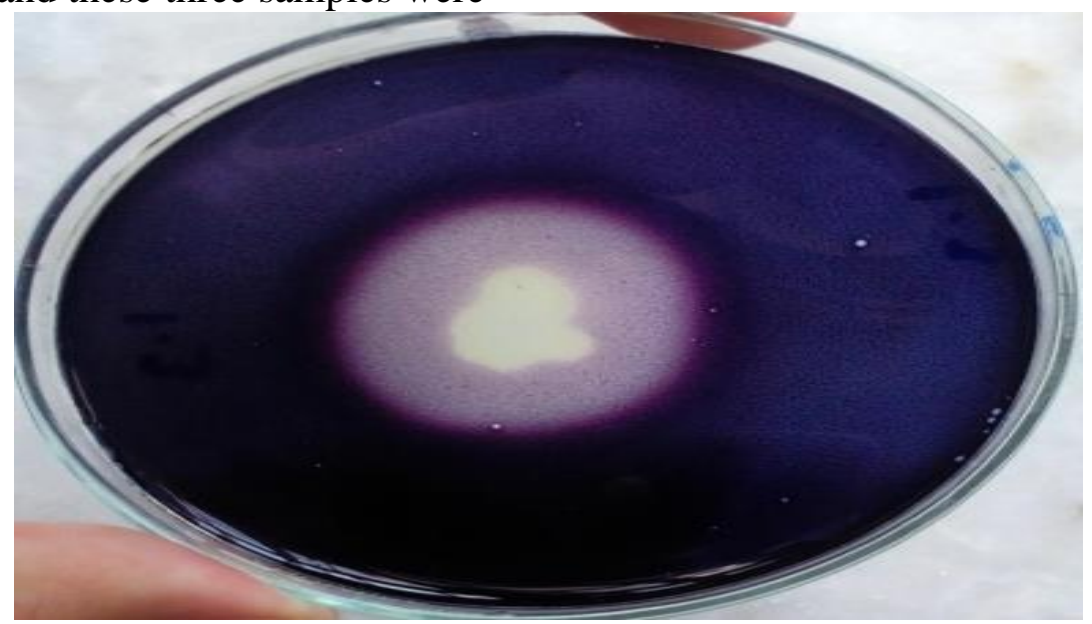

Figure 1. Screening of amylase producing bacteria isolated from salt mines

\section{Morphological and molecular identification}

Based on different results of gram staining and other biochemical tests, the selected amylolytic isolates were tentatively identified as described in Table 1.

The 16S rRNA gene of the selected isolates was amplified through polymerase chain reaction using $16 \mathrm{~S}$ rRNA universal primers F (5'GAGTTTGATCCTGGCTCAG-3') and R (5'GGCTACCTTGTTACGA-3'. The desired size of the amplified product was obtained as shown in Figure (2) and Table 2. Out of all positive selected bacterial strains only one strain SBA-5 was confirmed phylogenitically via robust technique of $16 \mathrm{~S}$ rRNA gene sequence (Table 2). To verify their phylogenetic position, the $16 \mathrm{~S}$ rRNA gene sequence of this isolate was analyzed, and Phylogenetic trees were constructed (Figure 3). According to the phylogenetic analysis, the isolate SBA-5 was finally identified as Bacillus subtilis sub specie inaquosorum. These results are in agreement with those of Roohi et al. (2012) who isolated different bacterial strains of different genera including Bacillus Spp from salt mines of Karak, Pakistan [13].

Table 1. Morphological identification through different Biochemical tests of the selected Bacterial Isolates

\begin{tabular}{|c|c|c|c|c|c|c|c|c|c|c|}
\hline $\begin{array}{l}\text { Strain } \\
\text { ID }\end{array}$ & $\begin{array}{l}\text { Gram } \\
\text { staining }\end{array}$ & Oxidase & Catalase & Motility & Indole & Urease & $\begin{array}{l}\text { Gas } \\
\text { fermentation }\end{array}$ & $\begin{array}{l}\text { Sugar } \\
\text { fermentation }\end{array}$ & $\begin{array}{l}\mathrm{H}_{2} \mathrm{~S} \\
\text { Fermentation }\end{array}$ & $\begin{array}{l}\text { Identified } \\
\text { strains }\end{array}$ \\
\hline SBA-5 & + & + & + & - & + & - & + & + & - & $\begin{array}{l}\text { Bacillus_su } \\
\text { btilis }\end{array}$ \\
\hline JIK-1.10 & + & + & + & + & - & + & + & + & - & $\begin{array}{l}\text { Bacillus_su } \\
\text { btilis }\end{array}$ \\
\hline BKH-A & + & - & + & - & + & + & + & + & - & $\begin{array}{l}\text { Bacillus_su } \\
\text { btilis }\end{array}$ \\
\hline
\end{tabular}




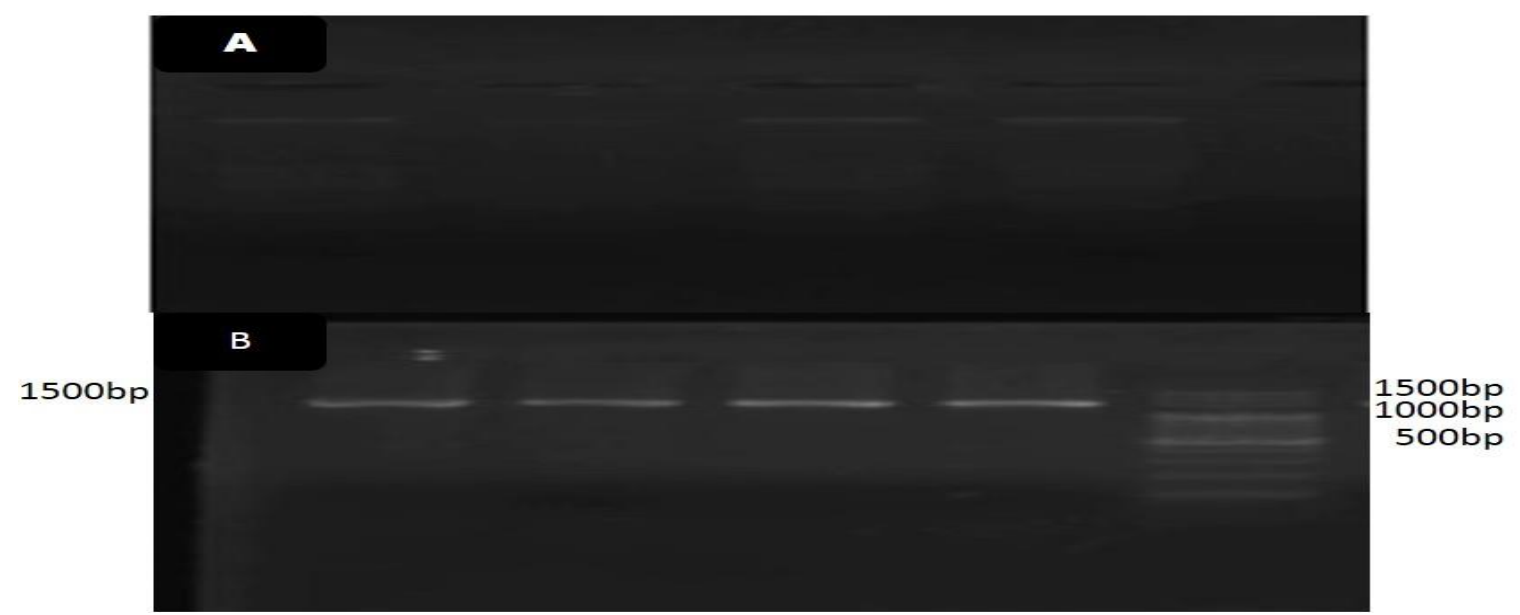

Figure 2. Gel Electrophoresis of Bacterial Genomic DNA and 16S rRNA Amplification of Amylolytic Bacterial Isolates. A (DNA about 3000bp), B (Amplified PCR Bands 1500bp)

Table 2. Molecular identification of the selected halotolerant/halophilic isolate based on 16S rRNA gene sequence

\begin{tabular}{|l|l|l|l|l|}
\hline $\begin{array}{l}\text { Lab } \\
\text { IB }\end{array}$ & $\begin{array}{l}\text { No. of nucleotides } \\
\text { sequence (bp) }\end{array}$ & Description & $\begin{array}{l}\text { Similarity } \\
\text { with \% }\end{array}$ & $\begin{array}{l}\text { Accession number of } \\
\text { 16SrRNA gene }\end{array}$ \\
\hline SBA-5 & 1299 & $\begin{array}{l}\text { Bacillus subtilis subsp. } \\
\text { inaquosorum }\end{array}$ & $97 \%$ & NR_116188.1 \\
\hline
\end{tabular}

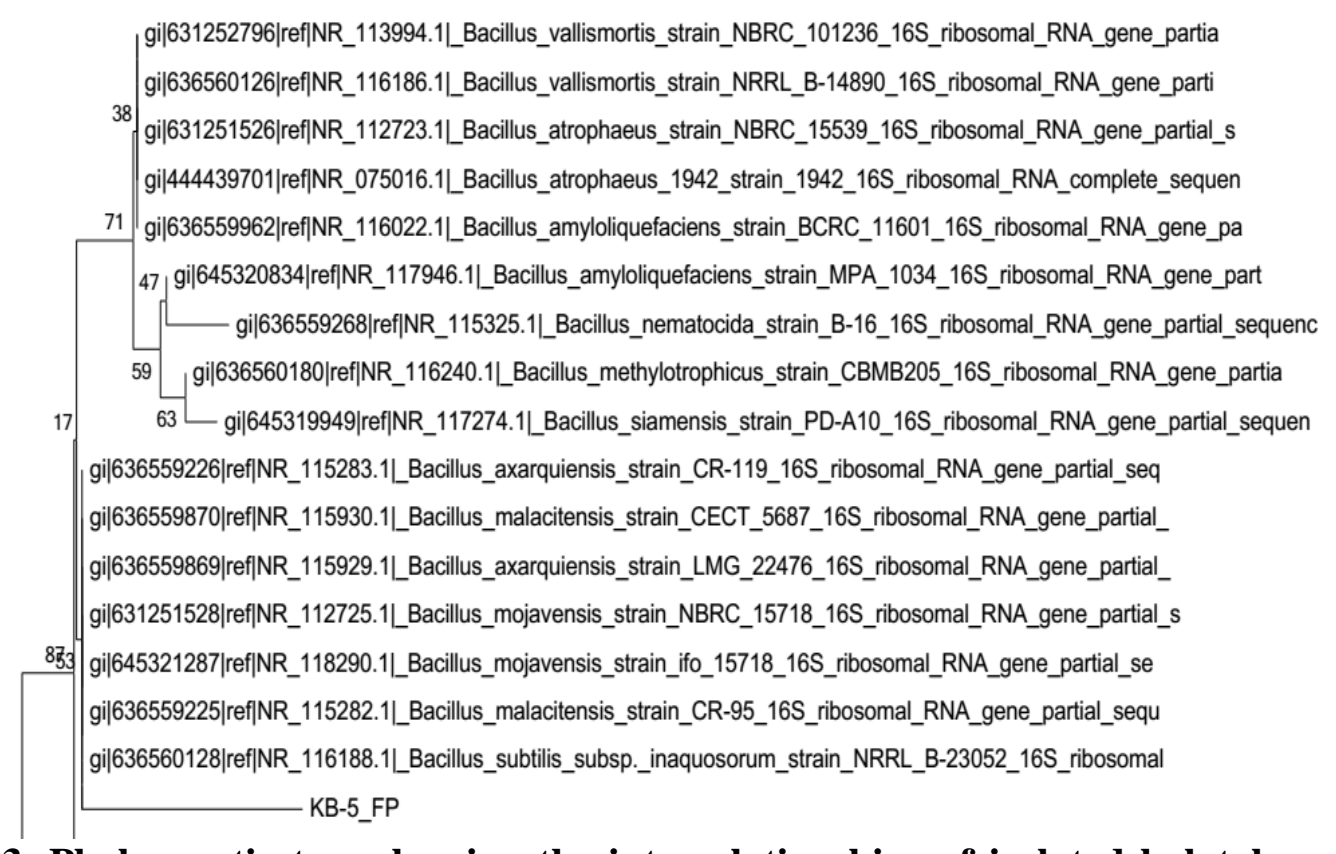

Figure 3. Phylogenetic tree showing the interrelationships of isolated halotolerant strains belonging to genus bacillus and the close relatives inferred from 16SrRNA gene sequence 
Effect of $\mathrm{pH}$ and temperature on microbial growth and amylase production Temperature and $\mathrm{pH}$ are the most important factor to influence microbial growth and enzymes production. The growth of the three selected isolates and their amylase production ability was determined at different $\mathrm{pH}$ values in order find out an optimum $\mathrm{pH}$ value for the isolates. Each isolate was showing different amylase production and different growth at every range of $\mathrm{pH}$. The isolate $B$. subtilis JIK-1.10 was showing best yield of amylase (34.16 $\mu \mathrm{g} / \mathrm{ml})$ on $\mathrm{pH} 7$ while its growth was also maximum $(0.517 \mathrm{OD})$ at $\mathrm{pH} 7$. The amylase production was decreasing at low and high $\mathrm{pH}$ values. So, the $\mathrm{pH} 7$ was referred as optimum for the production of amylase for the isolate JIK-1.10. The maximum production of amylase $(43.28 \mu \mathrm{g} / \mathrm{ml})$ and maximum growth $(0.655 \mathrm{OD})$ of the isolate SBA-5 was observed at $\mathrm{pH} 9$. Correspondingly, the highest yield of amylase $(60.06 \mu \mathrm{g} / \mathrm{ml})$ and growth $(0.909$ $\mathrm{OD}$ ) of the isolate BKH-A was observed at $\mathrm{pH}$ 10. Futher increase in $\mathrm{pH}$ slighltly decrease the growth of BKH-A strain and also amylase activity was reduced. This recommends $\mathrm{pH} 10$ as the suitable $\mathrm{pH}$ for BKH-A to express amylase enzymes. There is no significant difference between different $\mathrm{pH}$ values however, Figure 4 revealed trend that expression increases towards $\mathrm{pH} 10$, however, further increase in $\mathrm{pH}$ is resulting decrease in enzyme production. The decrease in enzyme production while increasing the $\mathrm{pH}$ is already reported by the authors $[8,10]$. Most of the amylase collected from biological source of normal climate prefer the neutral $\mathrm{pH}$ for expression. However, in this study the microbes belong to extreme environments and have the ability to express the enzymes even at elevated laboratory conditions. Incubation of the isolates at different temperatures and $\mathrm{pH}$ 9 considerably influenced the growth and the production of amylase. The isolate JIK1.10 showed maximum growth $(0.614 \mathrm{OD})$ at $37^{\circ} \mathrm{C}$ temperature and yielded maximum amylase $(40.57 \mu \mathrm{g} / \mathrm{ml})$ at $37^{0} \mathrm{C}$ (Figure $5 \mathrm{~A}$ ). Similarly, bacillus strain SBA-5 was showing best growth $(0.774 \mathrm{OD})$ at $37^{\circ} \mathrm{C}$ and maximum yield of amylase (51.14 $\mu \mathrm{g} / \mathrm{ml}$ ) (Figure 5B). These results showed that the most favorable temperature for growth of the isolate JIK-1.10 and SBA-5 was $37^{\circ} \mathrm{C}$. The isolate BKH-A showed maximum growth (0.663OD) as well as maximum amylase production $(43.81 \mu \mathrm{g} / \mathrm{ml})$ at $37^{\circ} \mathrm{C}$ (Figure 5C). Further raise in temperature reduced the enzyme production as well as growth of the isolate BKH-A, so it was found that the optimum temperature for the growth and amylase production of the different strains of Bacillus Subtilis is $37^{\circ} \mathrm{C}$. This temperature is also reported the optimum temperature for the growth of Bacillus Subtilis [8, 14].

In this study, the effect of $\mathrm{pH}$ and temperature on the amylase production is varied with that of bacterial growth. This means that bacterial growth was higher at elevated $\mathrm{pH}$ and temperature, however, the enzymes production decreased above certain level of $\mathrm{pH}$ and temperature. This indicated that there is no direct relation between growth and enzyme production. This is also reported by Ali et al (2012) and Khan et al (2011) for Bacillus spp. producing enzymes $[8,15]$. 


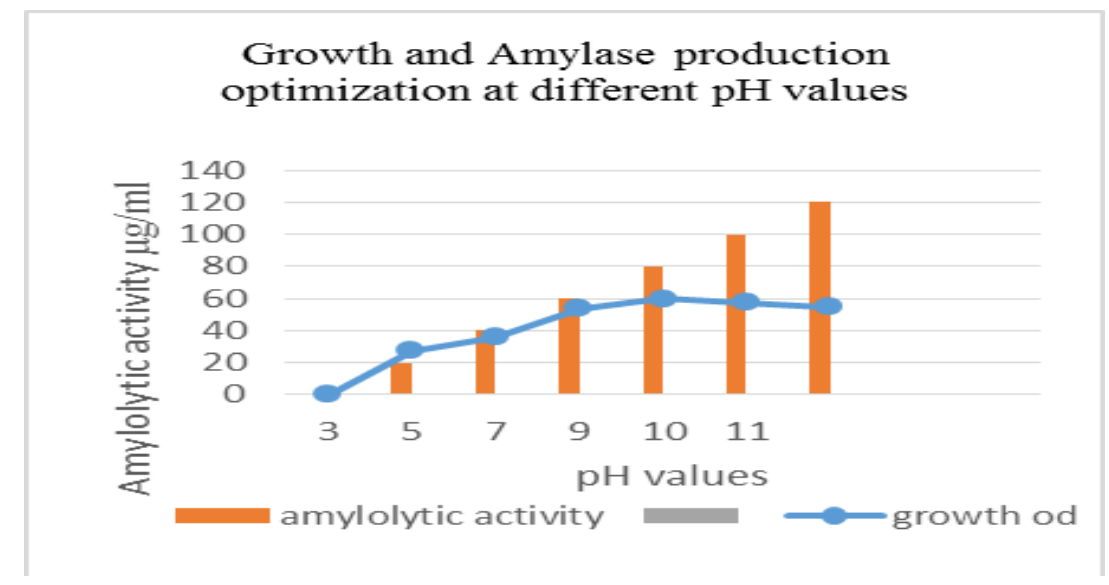

Figure 4. Effect of $\mathrm{pH}$ on amylase production of BKH-A strain at $37^{0} \mathrm{C}$

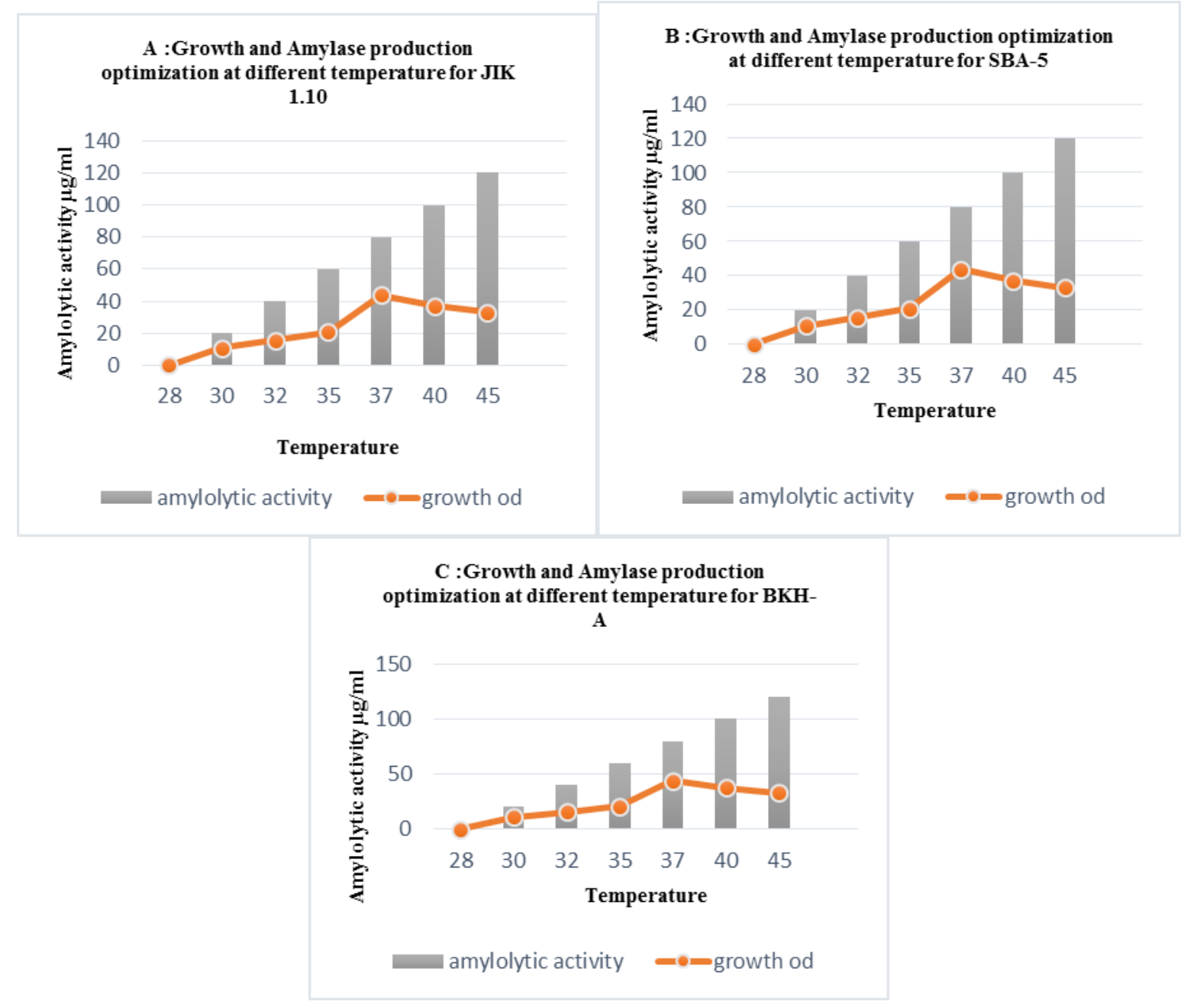

Figure 5. Effect of temperature on growth and amylase production of the isolates 


\section{Partial purification of amylases}

The amylase enzymes produced by Bacillus Subtilis strain (SBA-5) in the supernatant broth after centrifugation was collected and partially purified by TCA method. After extraction and partial purification of the protein product, SDS-PAGE was performed. The purity of amylases was then confirmed by SDS-PAGE and Zymographic analysis which showed specific band for purified amylase as given in Figure 6. The desired band size for amylase of $50 \mathrm{KDa}$ was obtained (Figure 6). Amylase enzymes with same molecular weight was reported in the previous literature $[15,16]$.

These results revealed that Bacillus Subtilis strain identified for amylase production from salt mines of Karak will be a good option for those industrial applications have high $\mathrm{pH}$ and temperature as common laboratory conditions.

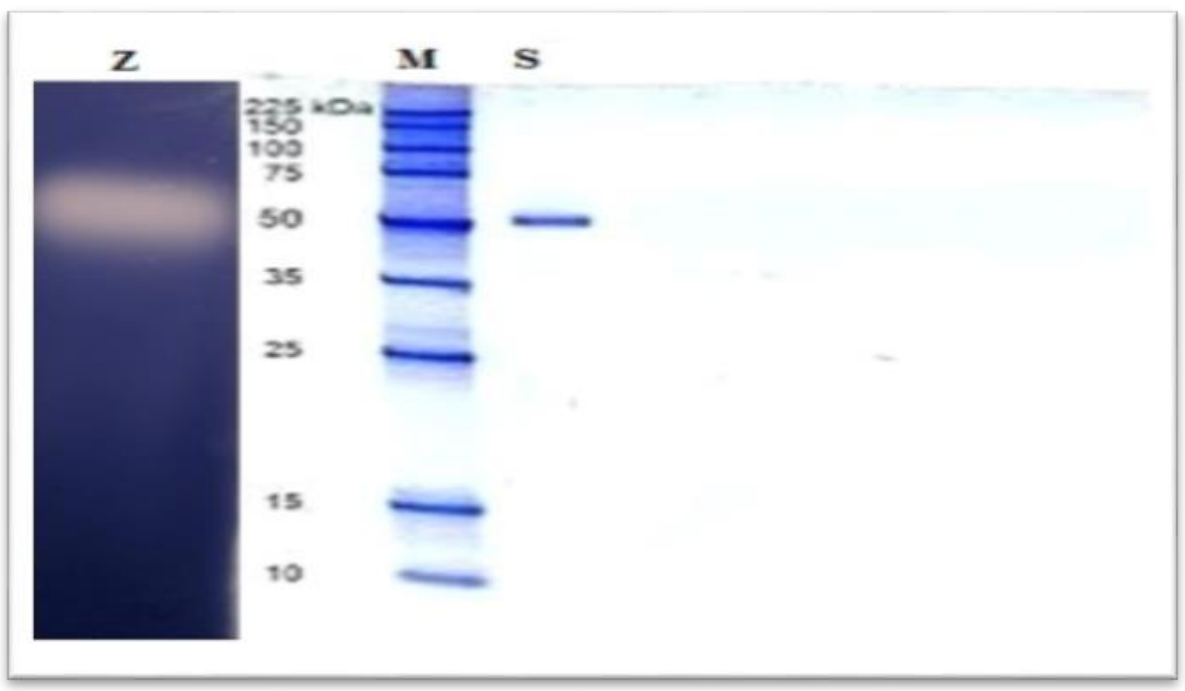

Figure 6. SDS-PAGE and ZYMOGHRAPHIC Analysis: M: Marker, Z: Zymography, S: Sample

\section{Conclusion}

In total, 43 amylase producing bacteria were isolated from the salt mines of three regions i.e Sabir Abad, Bahadar Khail and Jatta Ismail Khail of district Karak, Pakistan. Different morphological, biochemical and molecular tests identified three best amylase producers belong to Bacillus subtilis. SDSPAGE analysis has also confirmed the production of amylase enzyme. The strain SBA-5 identified as Bacillus subtilis exhibited high amylase production at $\mathrm{pH} 9$ and temperature $37^{\circ} \mathrm{C}$. The present study revealed that the salt mines of Karak, Pakistan have high population of halotolerant microorganism feasible for use under diverse environmental conditions, which can be of great importance for various bio-industrial applications.

\section{Authors' contributions}

Conceived and designed the experiments: W Shah, MD Khan \& N Ali, Performed all the experiments: W Shah, Analyzed the data: W Shah, N Ali, MD Khan, H Rahman \& M Qasim, Contributed reagents and analysis tools: S Ahmad, S Ullah, F Ullah \& B Khattak, wrote the manuscript: N Ali \& W Shah.

\section{References}

1.Wang S, Jeyaseelan J, Liu Y \& Qin W (2016). Characterization and amylase optimization of WangLB, a high amylase producing strain of Bacillus. Appli Biochem Biotech 180: 136-151 
2.Akhtar N, Ghauri MA, Iqbal A, Anwar MA \& Akhtar K (2008). Biodiversity and phylogenetic analysis of culturable bacteria indegeous to Khewra Salt mine of Pakistan and their industrial importance. Braz J Microb 39: 143150.

3.Woese CR \& Fox GE (1977). Phylogenetic nature of the prokaryotic domain: the primary kingdoms. Proc Natl Acad. Sci 74: 5088-5090.

4.Kumar S, Karan R, Kapoor S, Singh SP \& Khare SK (2012). Screening and isolation of halophilic bacteria producing industrially important enzymes. Braz J Microb 1595-1603.

5.Tango MSA \& Islam MR (2002). Potential for extremophiles for biotechnological and petroleum applications. Energy Sources 24: 543-559.

6.Kumar SS, Sangeeta R, Soumya S, Ranjan RP, Bidyut B, Mohapatra D \& Kumar DMP (2014). Characterizing novel thermophilic amylase producing bacteria from Toptapani hot spring, Odisha, India. Jundishapur J Microbiol 7(12): e11800.

7.Ahmed I, Yokota A \& Fujiwara T (2007). A novel highly boron tolerant bacterium, Bacillus boroniphilus sp. nov. Isolated from soil, that requires boron for its growth. Extremophiles 11: 217-224.

8.Ali N, Ullah N, Qasim M, Rahman H, Khan SN, Sadiq A \& Adnan M (2016). Molecular Characterization and growth optimization of halo-tolerant producing Bacillus Subtilis strain BLK-1.5 isolated from salt mines of karak, Pakistan. Extremophiles 20: 395-402.

9.Coronado MJ, Vargas C, Hofemeister J \& Ventosa A (2000). Production and biochemical characterization of $\alpha$ amylase from the moderate halophile
Halomonas meridiana. FEMS Microbiol Lett 183: 67-71.

10. Carrasco M, Villarreal P, Barahona S, Alcaíno J, Cifuentes V \& Baeza M (2016). Screening and characterization of amylase and cellulase activities in psychrotolerant yeasts. BMC Microbiol 16: 21.

11. Shanmugasundaran S, Eswar A, Mayavu P, Surya M \& Anbarasu R (2015). Screening and identification of amylase producing bacteria from Marakkanum Saltpan environment, Tamil Nadu, India. Asi J Biomed \& Pharm Sci 5 (48): 35-37.

12. Tamura K, Stecher G, Peterson D, Filipski A \& Kumar S (2013). MEGA 6: molecular evolutionary genetics analysis version 6.0. Mol Biol Evol 30: 2725-2729.

13. Roohi A, Ahmed I, Iqbal M \& Jamil M (2012). Priliminary isolation and charcetrization of halotoerant and halophilic bacteria from salt mines of Karak, Paksitan. Pak J Bot 44: 365370.

14. Sharmin S, Hossain MT \& Anwar MN (2005). Isolation and characterization of a protease producing bacteria Bacillus amovivorus and optimization of some factors of culture conditions for protease production. J Biol Sci 5: 358-362.

15. Khan I, Gupta P \& Vakhlu J (2011). Thermo-alkaliphilic halo-tolerant detergent compatible protease of Bacillus tequilensis MTCC9585. Afr J Microbial Res 5: 3968-3975.

16. Giroud E, Marin GB, Parada JL \& Raimboult M (1993). Purification and characterization of an extra cellular amylase from Lactobacillus plantarum strain A6. J Appl Bact 75: 276-282 